\title{
The impact of savings on economic growth in a developing country (the case of Kosovo)
}

Artur Ribaj ${ }^{*}$ and Fitim Mexhuani ${ }^{2}$

\author{
* Correspondence: artur.ribaj@ \\ outlook.com \\ ${ }^{1}$ Faculty of Economics, University of \\ Tirana, Tirana, Albania \\ Full list of author information is \\ available at the end of the article
}

\begin{abstract}
The correlation between savings and economic growth has been the subject of research for some well-known economists. This study provides further insight on such correlation by examining the case of Kosovo from both a qualitative and quantitative research methodology. The data used was from 2010 to 2017 and has been analyzed using the augmented Dickey-Fuller tests, Johansen cointegration tests, and Ganger causality test. The test of the unit root confirms stationarity, and the regression results showed that deposits have a significant positive impact on Kosovo's economic growth, because savings stimulate investment, production, and employment and consequently generate greater sustainable economic growth. Furthermore, loans and remittances also help boost the economy of Kosovo through their direct impact on investment. This paper confirms that countries whose national savings rate is high are not dependent on foreign direct investment; consequently, the risk arising from volatile foreign direct investment decreases significantly.

Keywords: Behavioral finance, Central banks and their policies, Corporate finance and governance, Financial institutions and services, Multiple or simultaneous equation models

JEL Classification: G4, E58, G3, G2, C3
\end{abstract}

\section{Springer Open}

\section{Background}

For the past 17 years, Kosovo has been experiencing major economic transformation, resulting in a significant economic growth. Although Kosovo has the highest economic growth compared to any other country in Southeast Europe, in the last 5 years, growth has decelerated fluctuating at an average pace of 3.8 to $4.4 \%$ as per CEIC data ${ }^{1}$. Accumulation of financial capital has been highlighted as the main factor regulating development to some degree-and since savings have increased in Kosovo, the situation begs the question of how an increase in savings contributes to the overall economic growth of a developing country like Kosovo.

\footnotetext{
${ }^{1}$ https://www.ceicdata.com/en/indicator/kosovo/real-gdp-growth
}

๑ The Author(s). 2021 Open Access This article is licensed under a Creative Commons Attribution 4.0 International License, which permits use, sharing, adaptation, distribution and reproduction in any medium or format, as long as you give appropriate credit to the original author(s) and the source, provide a link to the Creative Commons licence, and indicate if changes were made. The images or other third party material in this article are included in the article's Creative Commons licence, unless indicated otherwise in a credit line to the material. If material is not included in the article's Creative Commons licence and your intended use is not permitted by statutory regulation or exceeds the permitted use, you will need to obtain permission directly from the copyright holder. To view a copy of this licence, visit http://creativecommons.org/licenses/by/4.0/. 
Countries with higher rates of savings have had a faster economic growth than those with lower saving rates. Capital accumulation creates greater opportunities for production and the productivity of a country by providing an additional income stream for countries like Kosovo. In that regard, the United Nations Conference on Trade and Development "Development and Globalization: Facts and Figures"2 (2004) emphasizes that the main factor in increasing in-country capital is the increase of savings and that, in that regard, developing countries should prioritize programs that promote domestic savings, in order for capital to be invested towards the most productive practices. This paper based on literature review and empirical results confirm the impact of savings for sustainable economic growth of Kosovo and recommends politicians to implement policies that encourage gathering of savings in Kosovo banks from all citizens of Kosovo wherever they are.

\section{Methods}

To effectively implement the Johansen cointegration test and to find out the relationship between the gross domestic product (GDP) and domestic savings, this study analyzed the annual data of 10 commercial banks ${ }^{3}$ in Kosovo for the period of 2010-2017. The methods used for the analysis were the Dickey-Fuller (DF), augmented DickeyFuller (ADF), and the Ganger causality tests. The cointegration will inform us about the relationship in the short and long terms among the two variables, while on the other hand, causality indicates that (1) either $X$ is causing $Y$, (2) either $Y$ is causing $X$, or (3) both variables have a causal relationship with each other. Initially, the time series should be tested for stationarity through the ADF test and Philip Perron, usually the lower scale test and Granger. On the other hand, the augmented Dickey-Fuller test (ADF test) is a common statistical test used to test whether a given time series is stationary or not (Machine Learning Plus, 2019). If the series are non-stationary, then they should be included in the model in their stationary form and then proceed with analyzing the linear regression model. The equation is expressed in the form of: $Y_{t}=\mu+p \times$ $Y_{t-1}+\varepsilon_{t}$. The Ganger causality test denotes that any change of factor $X$ to an earlier time period $(t-k)$ affects the $Y$ variable at time $t$. Therefore, the hypothesis is $H_{0}: X$ does not cause (Granger cause) with $Y$ in the first regression; the growth of savings in the commercial banks of Kosovo positively affects sustainable growth in Kosovo.

\section{Results}

The methods used for the analysis of this study fit time series and mainly the Ganger causality, Dickey-Fuller (DF), and augmented Dickey-Fuller (ADF) tests. Initially, the time series are tested for stationarity through the ADF test. If the series is nonstationary, then they are included in the model in their stationary form and then analyzed through the linear regression model. The equation is as follows: $Y_{t}=\mu+p \times Y_{t-1}$ $+\varepsilon_{t}$.

We point out stationarity through Fig. 1 that refers to the GDP values for the period of 2010-2017. It is worth noting that if the series tends to increase or descend in time, then it can be said that the stationary condition may have been compromised.

\footnotetext{
${ }^{2}$ https://unctad.org/en/Docs/gdscsir20041_en.pdf

${ }^{3}$ Kosovo has licensed 11 banks. Ten of them are doing banking in the all cities of Kosovo. One of them is doing business only in north of Mitrovica, and it has less than 1\% of Kosovo deposits.
} 


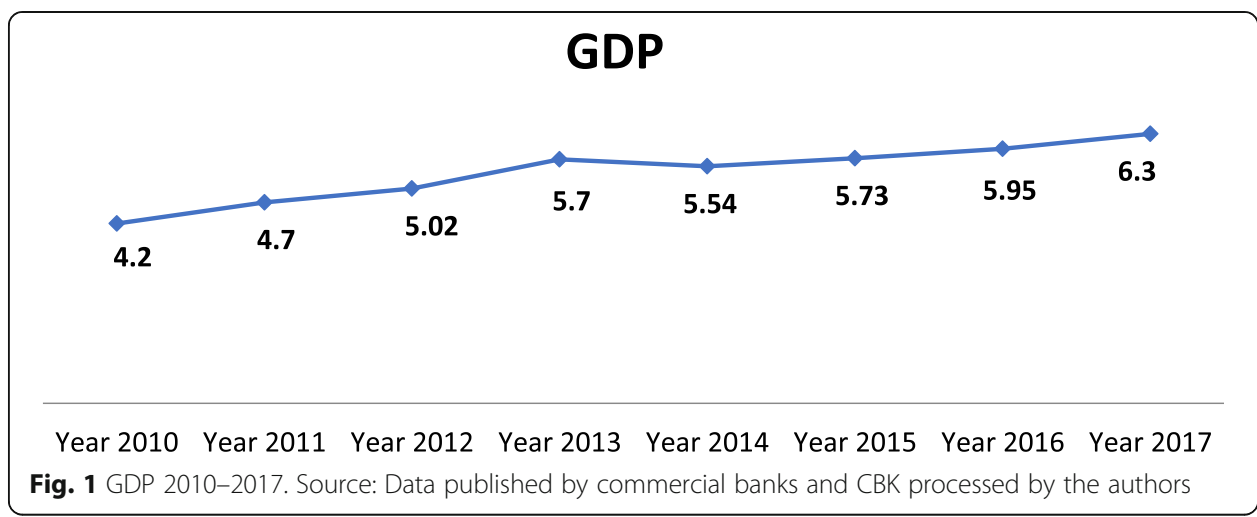

Otherwise, it can be a series of unit roots. Statistical data shows that GDP (nominal rate) has an upward trend from 2010 to 2017. Hence, the series of GDP values is a series of root units.

\section{Applying the Ganger causality test}

Before developing the appropriate model, we refer to the analysis of the Ganger causality test to analyze the role of each variable in the model in order to properly identify which one is the cause and which is the consequence. The data in Table 1 shows that none of the variables causes the "no Granger cause" between them. Hence, this allows for building a linear equation where GDP is the dependent variable, while deposits, remittances, and loans are independent variables. ${ }^{4}$

Upon successfully passing this test, we can continue conducting the following tests.

\section{Application of augmented Dickey-Fuller test}

We further analyze our series by referring to the augmented Dickey-Fuller (ADF) test as Table 2.

According to its data, the value of $t$-statistics in the ADF test is:

\begin{tabular}{ll}
\hline -statistics = $1.509>$ & -5.119 (1\% level) \\
& -3.519 (5\% level) \\
& -2.898 (10\% level) \\
\hline
\end{tabular}

As the results indicate, we are dealing with a non-stationary series where the probability value is 0.9947 .

Referring to EViews data regarding the first difference we observe that: $t$-statistics $=$ $-3.09>-5.11$ (1\% level), > 3.51 (5\% level), and <- 2.89 (10\% level).

Probability $F$ (statistics) $=0.03$ entails that our series is stationary in its first differences and is considered a series integrated into the first differences. The value of $R^{2}=0.70$ is a relatively high value. Since the value of $F$-statistic $=9.58$ (Table 2 ), we

${ }^{4}$ Note: The following tables have been developed with the aid of EViews software, which is an "econometric, statistics, and forecasting package." The software is widely available online and uses standardized tables and charts. Therefore, many of technical terms in these tables are repetitive and will most likely appear exactly the same in similar studies. For more information about the software used, refer to https://www.eviews.com/ Discovering/whatiseviews.html. 
Table 1 Ganger causality test

\begin{tabular}{llll}
\hline $\begin{array}{l}\text { Pairwise Granger causality tests } \\
\text { Date: August 17, 2018; Time: 09:48 } \\
\text { Sample: } \mathbf{2 0 1 0 - 2 0 1 7} \\
\text { Lags: } \mathbf{2}\end{array}$ & & & \\
\hline Null hypothesis: & Obs & F-statistic & Prob. \\
\hline Deposits does not Granger cause GDP & 6 & 952.073 & 0.0229 \\
GDP does not Granger cause DEPOSITS & & 58.3679 & 0.0922 \\
Credits does not Granger cause GDP & 6 & 41.9991 & 0.1085 \\
GDP does not Granger cause CREDITS & & 2.47142 & 0.4102 \\
Remittances does not Granger cause GDP & 6 & 0.71625 & 0.6412 \\
GDP does not Granger cause remittances & & 1.65366 & 0.4818 \\
Credits does not Granger cause deposits & 6 & 6.64755 & 0.2645 \\
Deposits does not Granger cause credits & & 5.40781 & 0.2909 \\
Remittances does not Granger cause deposits & 6 & 1.65669 & 0.4815 \\
Deposits does not Granger cause remittances & & 2.83038 & 0.3875 \\
Remittances does not Granger cause credits & 6 & 5.05721 & 0.3000 \\
Credits does not Granger cause remittances & & 3.98526 & 0.3339 \\
\hline
\end{tabular}

can reject hypothesis $H_{0}$ and include GDP in linear models. To reinforce this, Table 3 shows the data for the value of $R^{2}$ and the corresponding value of $F$-statistic as follows:

Therefore, we can develop a linear equation where GDP is the dependent variable, while deposits, remittances, and loans are independent variables. We tested this in the Ganger causality test applied in the previous steps. Considering what we want to test, and the previous test applications, we have built the following equations.

\section{Applying linear regression equations}

\section{Equation with deposit as the only factor}

Initially, we utilize a simple linear equation, considering only deposits as an independent variable. Hence, the equation is as follows:

$$
\mathrm{GDP}=1.842422+0.001444 \text { (deposits). }
$$

Considering the fact that Prob. $(F$-statistic $)=0.000$, and that the value of $F$-statistics is also relatively high $F$-statistics $=330.8186$, it appears that the model predicts $98.2 \%$ change in the value of GDP, resulting from a change in the factor deposit (reflected in Table 4). So, if the deposit factor increases by 1 unit, the value of GDP (nominal rate) will increase by 0.001444 times. The coefficient in front of the "deposit" factor has a positive value as expected. This means that deposits are an important factor in GDP growth, thus addressing the first objective of this study. Demonstrating the relationship between deposit accumulation/savings in Kosovo and Kosovo's economic growth, please refer to Table 4.

\section{Equation with two factors (deposits and loans)}

If the deposit factor increases the credit factor, further analyzing the effect of these factors is referred to again as the construction of the loan. Thus, the data presented in the table below shows that when deposits and loans are taken into account, GDP is calculated as GDP $=1.771828+0.001121$ (deposits) +0.000459 (loans). The equation 
Table 2 Augmented Dickey-Fuller test for GDP

\begin{tabular}{|c|c|c|c|c|}
\hline \multicolumn{5}{|c|}{$\begin{array}{l}\text { Null hypothesis: GDP has a unit root } \\
\text { Exogenous: Constant } \\
\text { Lag length: } 1 \text { (automatic-based on SIC, maxlag }=1 \text { ) }\end{array}$} \\
\hline & & & $t$-statistic & Prob.* \\
\hline \multicolumn{3}{|c|}{ Augmented Dickey-Fuller test statistic } & 1.509007 & 0.9947 \\
\hline \multirow[t]{3}{*}{ Test critical values: } & \multicolumn{2}{|l|}{$1 \%$ level } & \multicolumn{2}{|l|}{-5.119808} \\
\hline & \multicolumn{2}{|l|}{$5 \%$ level } & \multicolumn{2}{|l|}{-3.519595} \\
\hline & \multicolumn{2}{|l|}{$10 \%$ level } & \multicolumn{2}{|l|}{-2.898418} \\
\hline \multicolumn{5}{|c|}{$\begin{array}{l}\text { * McKinnon (1973) one-sided } p \text { values } \\
\text { Warning: Probabilities and critical values call } \\
\text { size of 6. } \\
\text { Augmented Dickey-Fuller test equation } \\
\text { Dependent variable: D (GDP) } \\
\text { Method: Least squares } \\
\text { Date: July 24, 2018; Time: 19:04 } \\
\text { Sample (adjusted): } 2012-2017 \\
\text { Included observations: } 6 \text { after adjustments }\end{array}$} \\
\hline Variable & Coefficient & Std. error & $t$-statistic & Prob. \\
\hline $\operatorname{GDP}(-1)$ & 0.190513 & 0.126251 & 1.509007 & 0.2284 \\
\hline $\mathrm{D}(\mathrm{GDP}(-1))$ & 0.951048 & 0.522726 & 1.819401 & 0.1664 \\
\hline C & -1.034414 & 0.819969 & -1.261529 & 0.2963 \\
\hline$R^{2}$ & 0.534089 & \multicolumn{2}{|c|}{ Mean-dependent var. } & 0.266667 \\
\hline Adjusted $R^{2}$ & 0.223482 & \multicolumn{2}{|c|}{ S.D.-dependent var. } & 0.061210 \\
\hline S.E. of regression & 0.053938 & \multicolumn{2}{|c|}{ Akaike info. criterion } & -2.695095 \\
\hline Sum squared resid & 0.008728 & \multicolumn{2}{|c|}{ Schwarz criterion } & -2.799215 \\
\hline Log likelihood & 11.08528 & \multicolumn{2}{|c|}{ Hannan-Quinn criterion } & -3.111897 \\
\hline F-statistic & 1.719502 & \multicolumn{2}{|c|}{ Durbin-Watson stat. } & 1.898931 \\
\hline Prob. (F-statistic) & 0.318020 & & & \\
\hline
\end{tabular}

is statistically valid since the value of Prob. $(F$-statistic $)=0.0000$ and the value of $F$ statistic $=158.2999$. The equation shows that the impact of deposits is higher compared to that of loans as the deposits' $\beta$ coefficient is higher despite both coefficients being positive and indicating that the growth of both factors affects the overall GDP growth rate. Yet, the probability of the deposit factor is smaller by 0.0339 , confirming, once again, the importance of the deposits factor compared to other factors. Demonstrating the relationship in the case of Kosovo in Table 5.

\section{Equation with remittances as the only factor}

When referring to the above equation, where remittances have a significant coefficient, we formulate another equation deliberating the correlation between GDP and remittances. As per the data in Table 7, the equation is as follows: GDP $=41.764384+$ 0.01043 (remittances). The $R^{2}=10.1 \%$ is a relatively small percentage compared to the other coefficients, which shows that remittances along cannot be a determining factor in GDP growth; they support but do not determine. This is the reason why first remittances, in interaction with other factors such as deposits or loans, have a significant impact on GDP. This is also confirmed by the value of Prob. ( $F$-statistic) $=$ 0.442 and the (rather low) value of F-statistic $=0.675427$. Demonstrating the relationship in the case of Kosovo in Table 6. 
Table 5 Building the model with deposits and loans as the factors

\begin{tabular}{|c|c|c|c|c|}
\hline \multicolumn{5}{|c|}{$\begin{array}{l}\text { Dependent variable: GDP } \\
\text { Method: Least squares } \\
\text { Date: August 17, 2018; Time: 09:52 } \\
\text { Sample: 2012-2017 } \\
\text { Included observations: } 8\end{array}$} \\
\hline Variable & Coefficient & Std. error & $t$-statistic & Prob. \\
\hline Deposits & 0.001121 & 0.000387 & 2.896729 & 0.0339 \\
\hline Credits & 0.000459 & 0.000538 & 0.853755 & 0.4322 \\
\hline C & 1.771827 & 0.216571 & 8.181280 & 0.0004 \\
\hline$R^{2}$ & 0.984453 & \multicolumn{2}{|c|}{ Mean-dependent var. } & 5.342500 \\
\hline Adjusted $R^{2}$ & 0.978234 & \multicolumn{2}{|c|}{ S.D.-dependent var. } & 0.686497 \\
\hline S.E. of regression & 0.101281 & \multicolumn{2}{|c|}{ Akaike info. criterion } & -1.461830 \\
\hline Sum squared resid & 0.051290 & \multicolumn{2}{|c|}{ Schwarz criterion } & -1.432040 \\
\hline Log likelihood & 8.847321 & \multicolumn{2}{|c|}{ Hannan-Quinn criterion } & -1.662756 \\
\hline F-statistic & 158.2999 & \multicolumn{2}{|c|}{ Durbin-Watson stat. } & 1.675376 \\
\hline Prob. (F-statistic) & 0.000030 & & & \\
\hline
\end{tabular}

\section{Equation involving deposits, remittances, and loans as factors}

Meanwhile, if we add the credit factor, the new model will appear as GDP $=1.769447$ +0.001193 (deposits) +8.10 (remittances) +0.000342 (loans). What is noticeable is that $R^{2}$ is still high at $98.5 \%$ even in this model, when all factors are considered together. Even remittances have a high coefficient, and this makes sense because a growth in deposits as a consequence of the large amounts of liquidity in the hands of citizens (due to remittances) brings positive effects to the economy. Statistically, this conclusion is valid as the value of Prob. $(F$-statistics $)=0.0004$ while $F$-statistics $=$ 86.77472. For the demonstration of the relationship in Kosovo, please refer to Table 8.

\section{Discussion}

The goal of any country is to achieve a high level of economic growth, as this would lead to better living standards, better prosperity, and a more comfortable life for its

Table 6 Building the model with remittances as the only factor

\begin{tabular}{|c|c|c|c|c|}
\hline \\
\hline \multicolumn{5}{|c|}{$\begin{array}{l}\text { Dependent variable: GDP } \\
\text { Method: Least squares } \\
\text { Date: August 17, 2018; Time: 10:04 } \\
\text { Sample: } 2012-2017 \\
\text { Included observations: } 8 \\
\text { Variable }\end{array}$} \\
\hline \multicolumn{3}{|c|}{$\begin{array}{clll}\text { Variable } & \text { Coefficient } & \text { Std. error } & \boldsymbol{t} \text {-statistic } \\
\text { Remittances } & 0.001043 & 0.001269 & 0.821843\end{array}$} & 0.821843 & 0.4326 \\
\hline C & 4.764384 & 0.746056 & \multirow[t]{2}{*}{6.386096} & 0.0007 \\
\hline$R^{2}$ & 0.101181 & \multicolumn{2}{|c|}{ Mean-dependent var. } & 5.342500 \\
\hline Adjusted $R^{2}$ & -0.048622 & \multicolumn{2}{|c|}{ S.D.-dependent var. } & 0.686497 \\
\hline S.E. of regression & 0.702989 & \multicolumn{2}{|c|}{ Akaike info. criterion } & 2.345366 \\
\hline Sum squared resid & 2.965159 & \multicolumn{2}{|c|}{ Schwarz criterion } & 2.365226 \\
\hline Log likelihood & -7.381464 & \multicolumn{2}{|c|}{ Hannan-Quinn criterion } & 2.211416 \\
\hline F-statistic & 0.675427 & \multicolumn{2}{|c|}{ Durbin-Watson stat. } & \multirow[t]{2}{*}{0.427663} \\
\hline Prob. (F-statistic) & \multicolumn{2}{|l|}{0.442591} & & \\
\hline
\end{tabular}


Table 7 Building the model with deposits and remittances as factors

\begin{tabular}{|c|c|c|c|c|}
\hline \multicolumn{5}{|c|}{$\begin{array}{l}\text { Dependent variable: GDP } \\
\text { Method: Least squares } \\
\text { Date: August 17, 2018; Time: 09:55 } \\
\text { Sample: 2012-2017 } \\
\text { Included observations: } 8\end{array}$} \\
\hline Variable & Coefficient & Std. error & $t$-statistic & Prob. \\
\hline Deposits & 0.001426 & $8.60 \mathrm{E}-05$ & 16.57972 & 0.0000 \\
\hline Remittances & 0.000143 & 0.000194 & 0.739663 & 0.4927 \\
\hline C & 1.806295 & 0.209199 & 8.634341 & 0.0003 \\
\hline$R^{2}$ & 0.983943 & \multicolumn{2}{|c|}{ Mean-dependent var. } & 5.342500 \\
\hline Adjusted $R^{2}$ & 0.977520 & \multicolumn{2}{|c|}{ S.D.-dependent var. } & 0.686497 \\
\hline S.E. of regression & 0.102928 & \multicolumn{2}{|c|}{ Akaike info. criterion } & -1.429583 \\
\hline Sum squared resid & 0.052971 & \multicolumn{2}{|c|}{ Schwarz criterion } & -1.399792 \\
\hline Log likelihood & 8.718331 & \multicolumn{2}{|c|}{ Hannan-Quinn criterion } & -1.630508 \\
\hline F-statistic & 153.1972 & \multicolumn{2}{|c|}{ Durbin-Watson stat. } & 1.399778 \\
\hline Prob. (F-statistic) & 0.000033 & & & \\
\hline
\end{tabular}

people (Sinha \& Sinha, 1998). In addition, governments in every country aim "to reduce poverty and increase the level of national income" (Rasmidatta, 2011). Therefore, achieving economic growth requires governments to adopt different types of policies such as promoting savings, stimulating investment, and increasing internal production (Rasmidatta, 2011); also, for developing countries in the SEE region such as Kosovo, the government needs to collaborate with Central Bank for investing in the financial education of youth which is "the future product of efforts that are made today" (Ribaj, Meçe, Cinaj, \& Kadrimi, 2020). Undoubtedly, investment contributes to aggregate growth; however, investment cannot be raised without increasing the amount of savings. In order for a country to achieve sustainable economic development, it needs to increase its aggregate savings, which will in turn contribute to greater

Table 8 Building the model with deposits, remittances, and loans as factors

\begin{tabular}{|c|c|c|c|c|}
\hline \multicolumn{5}{|c|}{$\begin{array}{l}\text { Dependent variable: GDP } \\
\text { Method: Least squares } \\
\text { Date: August 17, 2018; Time: 09:58 } \\
\text { Sample: } 2012-2017 \\
\text { Included observations: } 8\end{array}$} \\
\hline Variable & Coefficient & Std. error & $t$-statistic & Prob. \\
\hline Deposits & 0.001193 & 0.000480 & 2.487145 & 0.0677 \\
\hline Remittances & $8.10 \mathrm{E}-05$ & 0.000245 & 0.330938 & 0.7573 \\
\hline Credits & 0.000342 & 0.000691 & 0.494168 & 0.6471 \\
\hline C & 1.769447 & 0.238993 & 7.403744 & 0.0018 \\
\hline$R^{2}$ & 0.984867 & \multicolumn{2}{|c|}{ Mean-dependent var. } & 5.342500 \\
\hline Adjusted $R^{2}$ & 0.973517 & \multicolumn{2}{|c|}{ S.D.-dependent var. } & 0.686497 \\
\hline S.E. of regression & 0.111717 & \multicolumn{2}{|c|}{ Akaike info. criterion } & -1.238842 \\
\hline Sum squared resid & 0.049923 & \multicolumn{2}{|c|}{ Schwarz criterion } & -1.199121 \\
\hline Log likelihood & 8.955369 & \multicolumn{2}{|c|}{ Hannan-Quinn criterion } & -1.506743 \\
\hline F-statistic & 86.77472 & \multicolumn{2}{|c|}{ Durbin-Watson stat. } & 1.412433 \\
\hline Prob. (F-statistic) & 0.000427 & & & \\
\hline
\end{tabular}


investments and higher GDP growth. This also means that more savings, specifically in developing countries, "leads to less consumption, which could also result in a larger amount of capital investment and finally a higher rate of economic growth" (Rasmidatta, 2011). In that regard, Kosovo should aim to provide an open climate for encouraging the accumulation of savings because they bring a higher level of financial capital. As previously mentioned, financial capital is an important contributor to GDP growth as it increases opportunities for investing in production and innovation in a country by providing an additional income stream for society.

One way for governments to achieve economic growth, reduce poverty, and increase national incomes is to apply policies such as increasing savings to encourage an increase in investment in the domestic financial capital. Knowing that investment is one of the major factors influencing economic growth, one of the main ways to increase it is by expanding the size of savings/deposits in the commercial banks of developing countries.

Several studies have observed the relationship between savings and economic growth. Solow (1956) stressed the importance of saving on economic growth in 1956, when arguing that larger savings result in higher investments and increased production. McKinnon (1973) and Shaw (1973) reinforced the idea that savings are important in a country's economic development because they contribute to increased investment which accelerates economic growth. To explore the causal relationship between savings and economic growth, Sajid and Sarfraz (2008) used the correctional correction technique and correction vector and concluded that there is a long-term interrelationship between saving and GDP. Other scholars argue that the development of consumption habits creates a positive correlation between saving and GDP growth towards sustainable economic development in developing countries (Carroll, Overland, \& Weil, 2000). Furthermore, Anoruo and Ahmad (2001) conducted a study which "utilized co-integration and vector error correction model (VECM) to explore the causal relationship between economic growth and growth rate of domestic savings," and their results determined the existence of a "long-run relationship between economic growth and growth rate of savings" (Anoruo \& Ahmad, 2001, p. 1).

Thirlwall studied the role of financial liberalization in order to stimulate savings and investments, and as a result Egypt's economic growth. According to Thirlwall (2002) "the challenge of increasing savings is very important for Egypt in order to maintain the growth rate and increase the investment rate," while Romm (2003) analyzed the degree of interaction between private savings, investment, and growth through Johansen VECM and concluded that the growth of domestic savings/deposits has both a direct and indirect impact on the economic growth of a country.

Economic growth has a positive effect on domestic savings. Alguacil, Cuadros, and Orts (2004) sustain this conclusion in support of Solow's model which deliberates that higher savings lead to higher economic growth. Other studies express the opposite. Interestingly, Lean and Song (2008) conducted a study analyzing the relationship between China's domestic savings and economic growth, noting that economic growth in China was co-integrated with two other variables: saving households and increased savings by enterprises/businesses. In the short term, there is a cause-and-effect relationship between China's household economy and China's growth, while in the long run, there is an unjustifiable shortage of economic growth that leads to increased savings 
from enterprises/businesses. Another analysis of the cause-and-effect relationship between economy and savings for emerging economies was conducted by Misztal, who argued that there is a causal relationship between domestic savings/deposits and GDP growth (Misztal, 2011).

Developing countries, differently from developed countries have a much more important relationship between increasing domestic savings and economic growth of the country. Businesses in developed countries have varying financial resources available at low cost; they also have a major investment in infrastructure, technology, and development and do not necessarily need to attract foreign investors. This correlation does not occur in developed countries. In order to understand the causal relationship between savings and economic growth in Nigeria as a developing country, Olapido used the Toda, Yamamoto, Dolado, and Lutkepohl (TYDL) methodologies (Olapido, 2010). In this study, the variables of savings and economic growth were integrated into a long-term equilibrium relationship. The same methodology will be applied to discover this relationship in the case of Kosovo as well.

The autoregressive distribute lag (ARDL) method was applied by Budha (2014) to study the relationship between domestic savings, investment, and growth of Nepal, a developing country. Budha used the annual data reports for 1974-2010 for the study. At the end of the study, empirical results showed the existence of co-integration between domestic savings, investment, and gross domestic product. Each of these indicators was tested in a multiple regression analysis, as a dependent variable. Between the domestic savings and GDP, there is a two-way causality in the short run. The same result was achieved for investments and GDP. According to a study conducted by Sabra and Eltalla (2016), on the effects of domestic investment on economic growth, they concluded that the effects are significantly positive-that is, increases in domestic investments have contributed to the country's economic growth.

Another study comes from Hundie (2014), on the causal link between saving, investment, and economic growth, and it was based on annual data from periods 1969-1970 and 2010-2011. According to Hundie's survey results, there is cointegration between gross domestic savings, gross domestic investment, and Gross Domestic Product as dependent variables. Both the short- and long-term investments showed a significant positive impact on economic growth. "The current savings of Kosovars have served as the main potential of financial resources for capital investment in Kosovo" and have made an indisputable and irreplaceable contribution to the development and growth of the economy of Kosovo (Mexhuani \& Ribaj, 2018, p. 139). Increasing the accumulation of domestic savings would offer multiple benefits to Kosovo's economy.

Kosovo needs to mobilize internal savings to achieve the desired economic development. For this strategy to be implemented, it would require well-organized, competitive, and flexible financial institutions. Ribaj and Ilollari (2019) argued, in their article for Albania as part of Southeastern European (SEE) countries, that competition in the banking system is at a relatively low level and that no best practice is being applied by any other bank in SEE countries either. The Central Bank of Kosovo (CBK) and Kosovo's commercial banks have a major role to play in winning the trust of Kosovars and enhance the accumulation of domestic savings for the purpose of financial capital formation and then allowing that capital to be invested appropriately and freely 
in ventures that bring economic development to Kosovo. According to Cinaj, Meçe, Ribaj, and Kadrimi (2020), in developing countries, central bank and commercial banks continuously need to adjust policy implementation, legal and regulatory framework which govern banking activities. Lending is the main mechanism through which savings are transformed into investment in Kosovo. However, lending in developing countries is limited. Lack of lending to businesses in the Southeastern European developing countries (with Kosovo being a part of) creates a significant limitation for the development in these countries. The biggest limitations occur to businesses ${ }^{5}$ that invest in modern production lines, machineries, and technology that are important for reducing production costs, increasing productivity, and improving competitiveness. Based on the data and report-analyses of the Central Bank of Kosovo, we have identified these lending limitations in Kosovo. In addition, interviews with bank executives point out to two reasons for the slowdown in deposits growth and the discrepancy between the shortterm nature of deposits in Kosovo and the medium- and long-term necessity of funds by industries (as mentioned in the reports of the Central Bank of Kosovo in 2016 and 2017).

According to Agu (1984) "foreign capital cannot create permanent basis for higher standard of living in [the] future," on the contrary, "greater dependence on domestic sources facilitates a more successful implementation of any planned economic development." Since the end of the 2008 global crisis, aid trends for developing countries are declining and do not match current needs-countries need an evergrowing volume of financial resources with the lowest cost to boost their economic development, but this has become difficult to secure, even from depositors. According to Ribaj, Ilollari, and Scalera (2019) even after 10 years from the last financial crisis, people are still afraid to deposit all of their savings in banks and deposit withdrawals are considered to be the most "commonplace" activity. Dependence on foreign funds poses further disadvantages because it creates an economic dependence of the borrowing country from the lenders which might increase the foreign currency exchange risks (as exp. crisis case of Greece, Argentina, etc.).

Investment resources in most of the developing countries (as Kosovo) come largely from abroad, especially foreign direct investment and debt. However, the high dependence of developing countries on external sources limits their independency and these countries might face coercive policies for misusing their resources. Their economic downturn is further aggravated by debts. Similarly, many developing countries have a large deficit in current and commercial accounts, funded by foreign grants and loans. Even a small change in external capital flows can cause internal economic downturn. The accumulation of domestic savings will help reduce the vulnerability arising from dependence on foreign financing and provide a sustainable long-term financing base for investments in developing countries.

A rise in aggregate savings would yield larger investments associated with higher GDP growth. As a result, the high rates of savings increase the amount of capital and lead to higher economic growth in the country. Also, based on the theory of marginal inclination to save, revenue growth leads to the expansion of the savings rate. When

${ }^{5}$ According to Bisat, El-Erian, and Helbling in 1997 in a detailed analysis of growth, investment, and savings for Arab economies, it was noted that private sector investment was considered the engine of economic growth. 
talking about the relationship between savings and economic growth, it cannot be denied that an increase in aggregate savings would boost investment and promote economic growth. This is more evident in developing countries where the largest source of financial capital stems from savings deposited in commercial banks. Past experiences have shown that low saving rates have led to deficits in the budget and balance of the country's account.

\section{Conclusions}

The root test confirms stationarity and the hypothesis $H_{0}$ is disproved because the Granger causality test confirms a causal relationship between Kosovo's deposits $(X)$ and economic growth $(Y)$. Regression results showed that deposits have a significant positive impact on Kosovo's economic growth. This research concluded that the increase in the accumulation of savings from commercial banks in Kosovo has a positive effect on Kosovo's economic growth, as well as that remittances and loans are also an important enabling factor in driving the economy of Kosovo through a direct impact on investment.

Therefore, increasing the level of accumulation of domestic savings in the Kosovo banking system will help reduce unemployment, enable greater technological development, and increase Kosovo's GDP and people's well-being. This strategy will reduce the risks to the country's economy, as a major problem faced by some developing countries is typically the burden of external debts and dependence on international banks. Hence, the state of Kosovo should initiate strategies to promote the accumulation of domestic savings to accelerate sustainable economic growth in the country.

For further studies, we recommend a study on whether there should be some limit indicators set out in the CBK regulatory framework for limiting the large gap that exists between the interest rate on loans and the interest rate on deposits in Kosovo, or the establishment of some requirements for ensuring transparency in the construction of the interest rate on loans.

Abbreviations

ADF: Augmented Dickey-Fuller; ARDL: Autoregressive distribute lag; CBK: Central Bank of Kosovo; DF: Dickey-Fuller; GC: Ganger causality; GDP: Gross domestic product; SEE: Southeastern European; VECM: Vector error correction model

Acknowledgements

The authors acknowledge Kosovo's Central Bank and Commercial Banks for their support in providing data and information asked by them.

Authors' contributions

Artur Ribaj designed coordinated this research and drafted the manuscript. Fitim Mexhuani collected the data and carried out the data analyses. The authors read and approved the final article.

Funding

This article did not have donation or other funding sources.

Availability of data and materials

The datasets analyzed during the current study are available in the Central Bank of Kosovo repository, https://bqk-kos. org/?lang=en. All data generated during this study are included in this published article.

Competing interests

The authors declare that they have no competing interests.

Author details

${ }^{1}$ Faculty of Economics, University of Tirana, Tirana, Albania. ${ }^{2}$ Europian University of Tirana, Tirana, Albania. 
Received: 2 May 2020 Accepted: 17 November 2020

Published online: 08 January 2021

\section{References}

Agu, C. (1984). The role of commercial banks in mobilization and allocation of resources for development in Nigeria. Savings and Development, 8(2), 135-158.

Alguacil, M., Cuadros, A., \& Orts, V. (2004). Does saving really matter for growth? Mexico (1970-2000). Journal of International Development, 2, 281-290

Anoruo, E., \& Ahmad, Y. (2001). Causal relationship between domestic savings and economic growth: evidence from seven African countries. Oxford: Blackwell Publisher.

Bisat, A., El-Erian, M. A., \& Helbling, T. (1997). Growth, investment, and saving in the Arab economies. International Monetary Fund.

Budha, B. (2014). A multivariate analysis of savings, investment and growth in Nepal. EJON, 34(3).

Carroll, C. D., Overland, J., \& Weil, D. N. (2000). Saving and growth with habit formation. American Economic Review, 90(3), 341-355.

Cinaj V., Meçe M., Ribaj A., Kadrimi I., (2020). The need for improvement of external audit reports of banks (the case of banks in Albania which mainly belong to EU Banks). WSEAS Transactions on Business and Economics, 17, 539-547. https://doi. org/10.37394/232015.2020.16.55.

Sajid,G. M., \& Sarfraz, M. (2008). Savings and economic growth in Pakistan: An issue of causality. Pakistan Economic and Social Review, 46(1), 17-36.

Hundie, S. K. (2014). Savings, investment and economic growth in Ethiopia: evidence from ARDL approach to co-integration and TYDL Granger-causality tests. Journal of Economics and International Finance, 6(10), 232-248.

Lean, H., \& Song, Y. (2008). Domestic saving and economic growth in China. Asian Business and Economics Research Unit.

Machine Learning Plus (2019). https://www.machinelearningplus.com/time-series/augmented-dickey-fuller-test/.

McKinnon, R. I. (1973). Money and capital in economic development. Brookings Institution.

Mexhuani, F., \& Ribaj, A. (2018). Some factors for growing savings to be well-thought-out by key actors in Kosovo. European Journal of Marketing and Economics, 1(3), 131-140. http://journals.euser.org/files/articles/ejme_v1_i3_18/Mexhuani.pdf.

Misztal, P. (2011). The relationship between savings and economic growth in countries with different level of economic development. e-Finanse, Financial Internet Quarterly, 7(2), 17-29.

Olapido, O. S. (2010). Does saving really matter for growth in developing countries? The case of a small open economy. International Business and Economics Research Journal, 9(4). https://doi.org/10.19030/iber.v9i4.556.

Rasmidatta, P. (2011). The relationship between domestic saving and economic growth and convergence hypothesis: case study of Thailand. Södertörns Högskola, Department of Economics..

Ribaj A. and Ilollari O., (2019). Asymmetric information versus banks' costumer trust, Albania case linked with SEE countries. WSEAS Transactions on Business and Economics, 16, 288-297.

Ribaj A., Ilollari, O., Scalera, F., (2019). The unethical banking costs distrust of bank customers (Albania case as a model for SEE countries). WSEAS Transactions on Business and Economics, 16, 582-592.

Ribaj A., Meçe M., Cinaj V., Kadrimi I., (2020). Issues related to financial education of youth in a developing country (the case of Albanian youth). WSEAS Transactions on Business and Economics, 17, 140-152. https://doi.org/10.37394/23207.2020.17.16.

Romm, A. T. (2003). The relationship between savings and growth in Africa: an empirical study. TIPS/DPRU Forum.

Sabra, M. M., \& Eltalla, A. H. A. (2016). Foreign aid, domestic savings and economic growth in selected MENA countries. Business and Economic Research, 6(1), 352-362 Macro Think Institute.

Shaw, E. S. (1973). Financial deepening in economic development. Oxford University Press.

Sinha, D., \& Sinha, T. (1998). Cart before the horse? The saving-growth nexus in Mexico. Economics Letters, 61, 43-47.

Solow, R. M. (1956). A contribution to the theory of economic growth. Quarterly Journal of Economics, 70(1), 64-94.

Thirlwall, A. (2002). The mobilization of savings for growth and development in developing countries. Icfai University Journal of Applied Economics, /(1), 7-30.

\section{Publisher's Note}

Springer Nature remains neutral with regard to jurisdictional claims in published maps and institutional affiliations.

\section{Submit your manuscript to a SpringerOpen ${ }^{\circ}$ journal and benefit from:}

- Convenient online submission

- Rigorous peer review

- Open access: articles freely available online

High visibility within the field

- Retaining the copyright to your article

Submit your next manuscript at $\boldsymbol{\Delta}$ springeropen.com 